\title{
Forum
}

\section{Spatially Explicit Representation of State-and-Transition Models}

\author{
Caitriana M. Steele, ${ }^{1}$ Brandon T. Bestelmeyer, ${ }^{2}$ Laura M. Burkett, ${ }^{3}$ Philip L. Smith, ${ }^{4}$ and Steven Yanoff ${ }^{5}$
}

Authors are ${ }^{1}$ Assistant Professor, ${ }^{2}$ Research Ecologist, and ${ }^{3}$ Range Technician, USDA-ARS Jornada Experimental Range, New Mexico State University, Las Cruces, NM 88003, USA, ${ }^{4}$ Rangeland Management Specialist, Las Cruces District Office, Bureau of Land Management, Las Cruces, NM 88005, USA; and ${ }^{5}$ Conservation Biologist, The Nature Conservancy, Santa Fe, NM 87501, USA.

\begin{abstract}
The broad-scale assessment of natural resource conditions (e.g., rangeland health, restoration needs) requires knowledge of their spatial distribution. We argue that creating a database that links state-and-transition models (STMs) to spatial units is a valuable management tool for structuring ground-based observations, management planning for landscapes, and for housing information on the responses of land areas to management actions. To address this need, we introduce a multifactor classification system based on ecological sites and STMs that is directly linked to recent concepts of vegetation dynamics in rangelands. We describe how this classification was used as a basis for creating a spatial database and maps of ecological states. We provide an example of how the classification and mapping has been applied in over 1.2 million ha of public rangelands in southern New Mexico using aerial photo interpretation supplemented with existing inventory data and rapid field assessments. The resulting state map has been used by the Bureau of Land Management: 1) to design landscape-level shrub control efforts, 2) to structure and report district-wide rangeland health assessments, and 3) to evaluate locations for energy development. We conclude by discussing options for the development of state maps and their current limitations, including the use of satellite imagery and concepts for defining states. We argue that cataloging ecological states in a spatial context has clear benefits for rangeland managers because it connects STM concepts to specific land areas. State mapping provides a means to generate and store spatially explicit data resulting from tests of the propositions in STMs and conservation practices.
\end{abstract}

\section{Resumen}

La evaluación a gran escala de la condición de los recursos naturales (ejm. salud del pastizal, necesidades de restauración) requiere del conocimiento de la distribución espacial de los mismos. Argumentamos que estableciendo una base de datos que ligue modelos de estado y transición (MET) a unidades espaciales es una herramienta valiosa de manejo para estructurar observaciones basadas en el terreno, planeación del paisaje y para información de desarrollos habitacionales y las respuestas de las áreas de tierra y las acciones de manejo. Para dirigir esta necesidad introducimos el sistema de clasificación multifactorial basado en sitios ecológicos y MET que es directamente ligado a los recientes conceptos de dinámica de la vegetación y pastizales. Describimos cómo esta clasificación fue usada fundamentalmente para crear una base de datos para mapas de sitios ecológicos. Damos un ejemplo de cómo la clasificación y mapeo ha sido aplicado en arriba de 1.2 millones de hectáreas de pastizales públicos en el sur de Nuevo México usando interpretación de fotografía aérea complementado con datos de inventarios existentes y evaluaciones rápidas de campo. El mapa resultante ha sido usado por el Bureau of Land Management para 1) diseñar esfuerzos de control del paisaje con nivel de matorral, 2) estructurar y reportar evaluaciones de salud de pastizal a escala de distrito y, 3) evaluar lugares para desarrollo de energía. Concluimos con la discusión de opciones para el desarrollo de mapas de estado y sus actuales limitaciones incluyendo el uso de las imágenes de satélite y conceptos de definición de estados. Discutimos que catalogar los estados ecológicos en un contexto especial, tiene un claro beneficio para los manejadores de pastizales porque esto conecta los conceptos de MET para áreas de tierra específicas. El mapeo de estados provee un medio para generar y almacenar datos explícitamente de espacialidad, resultando de pruebas de propuestas de MET’s y prácticas de conservación.

Key Words: alternative states, ecological sites, geographic information systems, land classification, Soil Survey Geographic (SSURGO) Database

\footnotetext{
Research was funded in part by the Bureau of Land Management, Las Cruces District Office, USDA-NRI Biology of Weedy and Invasive Species Program, and a Rodney Johnson/ Katharine Ordway Stewardship Endowment grant from The Nature Conservancy.

Mention of a proprietary product does not constitute a guarantee or warranty by the US Department of Agriculture-Agricultural Research Service, New Mexico State University, US Department of the Interior-Bureau of Land Management, The Nature Conservancy, or the authors, and does not imply its approval to the exclusion of other products that also may be suitable.

Correspondence: Caitriana Steele, USDA-ARS Jornada Experimental Range, PO Box 30003 MSC 3JER, Las Cruces, NM 88003, USA. Email: caiti@nmsu.edu

Manuscript received 7 March 2011; manuscript accepted 8 January 2012.
}

\section{INTRODUCTION}

Over the last two decades, ecosystem management strategies have increasingly focused on ecological processes and dynamics that support a variety of ecosystem services (Briske et al. 2003). These changes are evident in the increasing use of state-andtransition model (STM) concepts by land managers in the Western United States for field-level assessment of vegetation and soil condition at discrete locations (points or transects). Field-level assessments link small land areas to information in STMs, but they cannot be used for comprehensive management 
of large landscapes (Fuhlendorf et al. 2006; Briske et al. 2008). The shift to incorporate more information on ecological processes accompanies a growing focus on landscape scale decisionmaking (Karl and Sadowski 2005; Forbis et al. 2007; Ludwig et al. 2007). Thus, there is a need to represent information in STMs at the scale of extensive landscapes.

Because STMs are already used for land management decision-making, it is logical to identify the information within these models that can be used for input into a spatial data set. STMs use diagrams and data-supported narratives to describe the dynamics of plant communities and associated changes in ecosystem services, land uses, and management needs (Westoby et al. 1989; Briske et al. 2003; Bestelmeyer et al. 2004). STMs formally represent plant community dynamics by first characterizing discrete plant community types (community phases) that can occur at the same location, usually based on dominant plant species. Following current concepts employed by federal land management agencies, multiple community phases are classified to the same ecological state when shifts among community phases are reversible without energy-intensive interventions (e.g., via by succession; Stringham et al. 2003). Community phases are classified to distinct ecological states (i.e., alternative states) when succession alone does not result in recovery of the original community and energy-intensive interventions (restoration pathways) are needed to reverse change, or reversal is impossible (Briske et al. 2008). Thus, the classification of a plant community phase to an alternative state asserts the existence of an ecological threshold (Suding and Hobbs 2009) beyond which changes in plant community structure, rates of ecological processes, and ecosystem services are large compared to community phase shifts within states. In contrast to community phase shifts, state changes from the "reference" or historical state are typically persistent and selfreinforcing, and their effects on society are comparatively severe, such as through soil erosion or changes to fire frequency (Briske et al. 2008). Consequently, the identity of the ecological state of a land area contains especially valuable information for use in the design of management actions, assessment, and monitoring (e.g., Karl and Herrick 2010; Rumpff et al. 2011).

In order to establish the identities of ecological states present in a landscape, it is necessary to select a spatial framework upon which to build the new data set. STMs developed by the Natural Resources Conservation Service (NRCS) are explicitly linked to individual ecological sites. Ecological sites are soiland climate-based classes of land that differ in potential plant communities and responses to disturbance and, therefore, use and management (Moseley et al. 2010). Ecological sites are linked directly to soil map unit components (soil series phases) of the National Cooperative Soil Survey, effectively grouping soil components that have similar ecological characteristics. Due to limitations in the scale of soil mapping, soil mapping units represent spatially one or more ecological sites.

The relationship of STMs to soil mapping suggest that creating a spatial database of ecological state land units is achievable, although not without challenges. The first challenge is to identify single or multiple attributes from the STMs that provide the relevant information needed to represent states as spatial entities. Associated with attribute identification is the selection of a classification system with which to categorize those attributes. Second, the data needed and methods by which data are interpreted to compile the map must be determined. Finally, a suitable data delivery format must be agreed upon between the data provider and data user. These tasks require that we understand how the data will be used by natural resource professionals and the technologies available for producing and updating a spatial database and map. We must also recognize when changes in the availability of data, technologies, and concepts to produce such maps warrant novel mapping approaches.

In this paper, we describe the issues inherent in, and approaches for, creating a classification system and spatial database of ecological states. Our approach was inspired by, and partly based on, older vegetation maps developed by the Bureau of Land Management (BLM) in the 1970s (the Site Vegetation Inventory Method) and facilitated by the recent availability of digital soil survey data and high-resolution imagery. We use our efforts to develop an ecological state database in public rangelands in southern New Mexico to demonstrate a workable approach and to discuss its benefits and limitations. We approach this presentation from both a conceptual and technical standpoint in order to provide readers with a rationale for state mapping, its potential benefits, as well as a practical understanding of the opportunities and limitations of such efforts.

\section{STUDY AREA}

Our experiences with the development and use of ecological states maps pertain to the BLM Las Cruces District Office (LCDO), an area of ca. 1.2 million ha in the southwestern quarter of New Mexico. The BLM LCDO comprises public land in six counties predominantly within Major Land Resource Area (MLRA) 42, Southern Desertic Basins, Plains and Mountains region (USDA-NRCS 2006). MLRA 42 is characterized by low precipitation $(205-355 \mathrm{~mm})$, and soils are Aridisols, Entisols, Mollisols, and Vertisols supporting desert grassland, savanna, and shrubland vegetation (USDA-NRCS 2006). The invasion or encroachment of native shrubs associated with the loss of perennial grasses and soil erosion is the dominant state transition process of management concern in this MLRA. Other important state transition processes in MLRA 42 include 1) the replacement of highly palatable native perennial grass species with less palatable native perennial grass species, 2) the replacement of native perennial grass species with exotic perennial grass species, and 3) the loss of all vegetation coupled with severe soil degradation.

\section{ECOLOGICAL SITES: A FOUNDATION FOR CLASSIFICATION AND MAPPING}

The production of an ecological state map begins with spatial data on ecological sites. A set of ecological sites is common to either the MLRA or Land Resource Unit level of the Land Resource Hierarchy of the NRCS (Bestelmeyer et al. 2009). Ecological sites, in turn, group one or more soil map unit components that exhibit similar properties. To create a spatial database and map of ecological sites, it is necessary to link soil map unit components from the NRCS Soil Survey Geographic 
Table 1. Ecological site types recognized within Major Land Resource Area (MLRA) 42 of southwestern New Mexico.

\begin{tabular}{|c|c|c|}
\hline Ecological site type & Criteria & MLRA 42 ecological site \\
\hline $\begin{array}{l}1 \text { Historical } \\
\text { grasslands }\end{array}$ & $\begin{array}{l}\text { At potential, vegetation is dominated by dense, continuous } \\
\text { stands of historically dominant perennial grass species. }\end{array}$ & $\begin{array}{l}\text { Bottomland, Salty Bottomland, Salt meadow, Draw, Sandy, Shallow } \\
\text { sandy, Limy, Loamy sand, Loamy, Loamy bottom, Clayey, Gyp } \\
\text { Upland, Malpais, Swale, Gyp interdune (dry), Clay loam upland }\end{array}$ \\
\hline $\begin{array}{l}2 \text { Historical } \\
\text { savanna }\end{array}$ & $\begin{array}{l}\text { At potential, there is a significant woody component (shrubs or trees) } \\
\text { within a continuous perennial grass matrix. Larger sizes of shrubs } \\
\text { and trees, coupled with more age distinguish the historical savanna } \\
\text { from the shrub invaded type } 1 \text { ecological site. }\end{array}$ & $\begin{array}{l}\text { Deep sand (MLRA 42.2), Gravelly, Gravelly Loam, Gravelly sand, } \\
\text { Hills, Limestone hills, Gyp hills, Gyp outcrop, Salt flats, Malpais, } \\
\text { Shallow }\end{array}$ \\
\hline $\begin{array}{l}3 \text { Historical } \\
\text { woodlands }\end{array}$ & $\begin{array}{l}\text { At potential, vegetation is dominated by woody species } \\
\text { with perennial grasses as co- or subdominant. These } \\
\text { sites may also feature subdominant subshrubs. }\end{array}$ & $\begin{array}{l}\text { Deep sand (MLRA 42.3), Sand Hills, Salt meadow, Vegetated } \\
\text { gypsum dunes }\end{array}$ \\
\hline
\end{tabular}

(SSURGO) Database with ecological site classifications provided in nonspatial tables. An example of how relationships can be built between nonspatial data and soil map unit components is given in Di Luzio et al. (2004). It is noteworthy that SSURGO soil map unit components usually describe soil complexes or associations that may translate to multiple ecological sites per soil map unit polygon (e.g., Forbis et al. 2007).

\section{ECOLOGICAL STATE CLASSIFICATION SCHEME}

Although ecological sites classify the ecological potential of an ecosystem, the ecological site land unit is not appropriate for directly mapping ecological states because each ecological site may be observed in one of several states depending on historical events. Therefore, we must distil the logic within STMs to develop a classification system for ecological states within ecological sites. The first task was to decide between ecological states and community phases as the basis for the classification scheme. Mapping can involve both states and community phases, but we have focused on states for two primary reasons. First, state identity is typically persistent compared to community phase identity within states, which can shift abruptly with common events such as variations in seasonal rainfall or fire. Thus, maps of community phases could become quickly obsolete. Second, as described earlier, the characteristics of ecological states have important implications for sustainability and restoration efforts (Briske et al. 2008).

There are also two practical reasons for focusing on states rather than community phases. First, due to their basis in general structures and ecological processes rather than species composition, states can be represented as generalized classes that apply to multiple ecological sites. Generalization of states is critical to produce a workable classification for large landscapes or regions. If, for example, we considered each ecological state of each ecological site as a distinct class, we estimate about 300 classes would be recognized within our study area. This number of potential classes is unworkable both in terms of assigning and interpreting the classification. Generalizing ecological states can reduce the potential of hundreds of classes to, in our example, eight. Such generalization is not possible with community phases because they represent distinct suites of species rather than generalizable structures and processes. Second, contiguous areas in a given state are more readily distinguished than community phases through image classification techniques (see Mapping
Ecological States below). It is often possible to visually resolve functional types of plants such as shrubs or grass patches from fine resolution imagery, but it is not possible to determine species identity reliably. Below, we describe in detail how we generalized state classes to illustrate how such efforts can be approached elsewhere.

To be able to generalize state classes, it was first necessary to identify and categorize ecological sites that exhibited similar states and transitions. Within our study area, the presence and amount of woody cover in the reference state varies among ecological sites, so we used this criterion for categorizing ecological sites into types (Table 1). Type 1 Ecological Sites are those that exhibit little woody cover in the reference state. Type 2 Ecological Sites have a significant woody plant cover within a grassland matrix in the reference state. Type 3 Ecological Sites are dominated by woody plants in the reference state.

We then developed generalized concepts for ecological states based upon the STMs developed for the ecological sites represented in our mapping effort (Table 2, see Bestelmeyer et al. 2009). The generalized states are distinguished by plant functional groups, plant patch and soil erosion patterns, and inferred ecological processes that apply to STMs of several ecological sites. Particular generalized states, however, may apply to one ecological site type but not others. For example, a shrub-invaded state would not apply to a Type 2 ecological site that possesses shrubs in the reference state. Superficially, it may appear that this generalization oversimplifies the original information contained in the STMs. On the contrary, because the data are tied to the SSURGO soil polygons, the generalized state classes can be translated directly to the box and arrow diagrams and the narrative elements of the STMs for individual ecological sites.

\section{MAPPING ECOLOGICAL STATES}

Prior to mapping ecological states, third-order soil map unit polygons were classified to their component ecological sites. The data were then overlain on fine resolution, orthorectified photographic imagery that meets National Map Accuracy Standards as specified in the digitizing standards for producing soil survey base map data (USDA-NRCS 2009). Geographic Information System analysts delineated state map units through interpretation of digital orthophoto quarter quadrangles from 2005 or National Agricultural Imagery Program imagery from 
Table 2. Generalized state classes (and specific terms applied to ecological site types in italics) used in state mapping within Major Land Resource Area 42 of southwestern New Mexico (after Bestelmeyer et al. 2009).

\begin{tabular}{|c|c|c|c|}
\hline General state & Concept for general state & Classification code & Present in ecological site types \\
\hline $\begin{array}{l}\text { Reference } \\
\text { Grassland, Savanna, Shrub- } \\
\text { land/woodland/forest }\end{array}$ & $\begin{array}{l}\text { Site near maximum productivity, populated with full complement } \\
\text { historically dominant species. }\end{array}$ & 1 & $1,2,3$ \\
\hline $\begin{array}{l}\text { Altered reference } \\
\text { Altered grassland, Altered } \\
\text { savanna, Altered shrub- } \\
\text { land/ woodland/forest }\end{array}$ & $\begin{array}{l}\text { Site often exhibits reduced total annual and/or forage production. If } \\
\text { historically dominant species are present, these are fragmented } \\
\text { and/or subdominant to less-palatable, grazing-tolerant or ruderal } \\
\text { species. Evidence of soil erosion. }\end{array}$ & 2 & $1,2,3$ \\
\hline $\begin{array}{l}\text { Shrub/tree-invaded } \\
\text { Shrub-invaded grassland }\end{array}$ & $\begin{array}{l}\text { Woody plants expanding into perennial grassland become dominant } \\
\text { over or codominant with grazing-tolerant grasses. Remnant patches } \\
\text { of historically dominant grass species may persist in woody plant } \\
\text { interspaces suggesting that competitive exclusion is incomplete and/ } \\
\text { or soil degradation infrequent. Soil redistribution to shrub patches } \\
\text { apparent. Reduced grass connectivity leads to reduced fire } \\
\text { occurrence. }\end{array}$ & 3 & 1 \\
\hline $\begin{array}{l}\text { Shrub/tree-dominated } \\
\text { Shrub-dominated grassland, } \\
\text { Shrub-dominated savanna }\end{array}$ & $\begin{array}{l}\text { Soil is redistributed to and biological activity is centered beneath } \\
\text { expanding woody plants. Scattered perennial grass cover }(<10 \%) \\
\text { exists as relict patches in shrub interspaces. Grazing tolerant or } \\
\text { ruderal grass species occur under shrubs. Evidence of interspace } \\
\text { erosion/soil degradation, resource retention is low. Facilitation } \\
\text { between shrubs and grasses sustains remaining grasses. }\end{array}$ & 4 & 1,2 \\
\hline $\begin{array}{l}\text { Expansion shrubland/ } \\
\text { woodland }\end{array}$ & $\begin{array}{l}\text { Near complete loss of perennial grasses in shrub interspaces. } \\
\text { Perennial grass species may occur as isolated plants. Woody plants } \\
\text { are dominant. Extensive evidence of interspace erosion/soil } \\
\text { degradation, resource retention is very low. }\end{array}$ & 5 & 1,2 \\
\hline Bare/annuals & $\begin{array}{l}\text { Woody and perennial grass species are almost entirely absent. } \\
\text { Annual vegetation, if present, is dominant. Extensive evidence of } \\
\text { interspace erosion/soil degradation, resource retention is very low. }\end{array}$ & 6 & $1,2,3$ \\
\hline Exotic invaded & $\begin{array}{l}\text { Presence of exotic woody, grass, or forb species. Suggests that } \\
\text { these invading species may come to dominate the site over time } \\
\text { but do not yet govern ecosystem function. } \\
\text { Exotic species (e.g., Eragrostis lehmanniana Nees, Bromus rubens } \\
\text { L., Pennisetum setaceum [Forssk.] Chiov, Brassica tournefortii } \\
\text { Gouan, Tamarix ramosissima Ledeb.) present or common. Fire } \\
\text { and/or livestock grazing preferences may favor growth and } \\
\text { reproduction of exotic species relative to natives. }\end{array}$ & 7 & $1,2,3$ \\
\hline Exotic dominated & Exotic species are common and dominate ecosystem function of site. & 8 & $1,2,3$ \\
\hline
\end{tabular}

2009 (1-m spatial resolution). These analysts were familiar with the landscapes of southern New Mexico as well as the STMs. Skilled photo-interpreters can identify units that are relatively homogeneous ecologically and that integrate multiple factors such as patterns in cover and landforms (Zonneveld 1989).

Forbis et al. (2007) note that third-order soil mapping units they encountered contained several ecological sites, but there was no indication in the spatial data where these ecological sites occurred. This was also true of the soils data available in our study area. In arid rangeland areas, third-order soil map units were typically produced at spatial scales that obscure the variation of individual soil types and usually contain soil complexes or associations. To try to distinguish between different ecological sites within a single soil map unit, we cut polygons to delineate fine spatial resolution features visible in the imagery at scales between 1:2000 and 1:5000. Our intention was to try to reduce the heterogeneity due to soils contained within mapping units and to ensure that map unit polygons contained ecological sites and vegetation communities that were as uniform as possible.

Mapping at scales between 1:2000 and 1:5000 resulted in map units that ranged in size from 1 or 2 ha to 4000 ha, depending on the degree of landscape heterogeneity. We anticipate that in other regions, where vegetation cover is more continuous and soil heterogeneity is expressed at coarser scales, that state mapping could be conducted at coarser scales (soil map unit polygons may not require editing) and with greater dependence on automated remote sensing techniques.

Certain methodological details are important to point out to those embarking on state mapping approaches. Among the most important of these is to map by subdividing existing SSURGO soil polygons, thereby preserving polygon boundary topology of the original soils data (e.g., Figs. 1a-1c). We did 

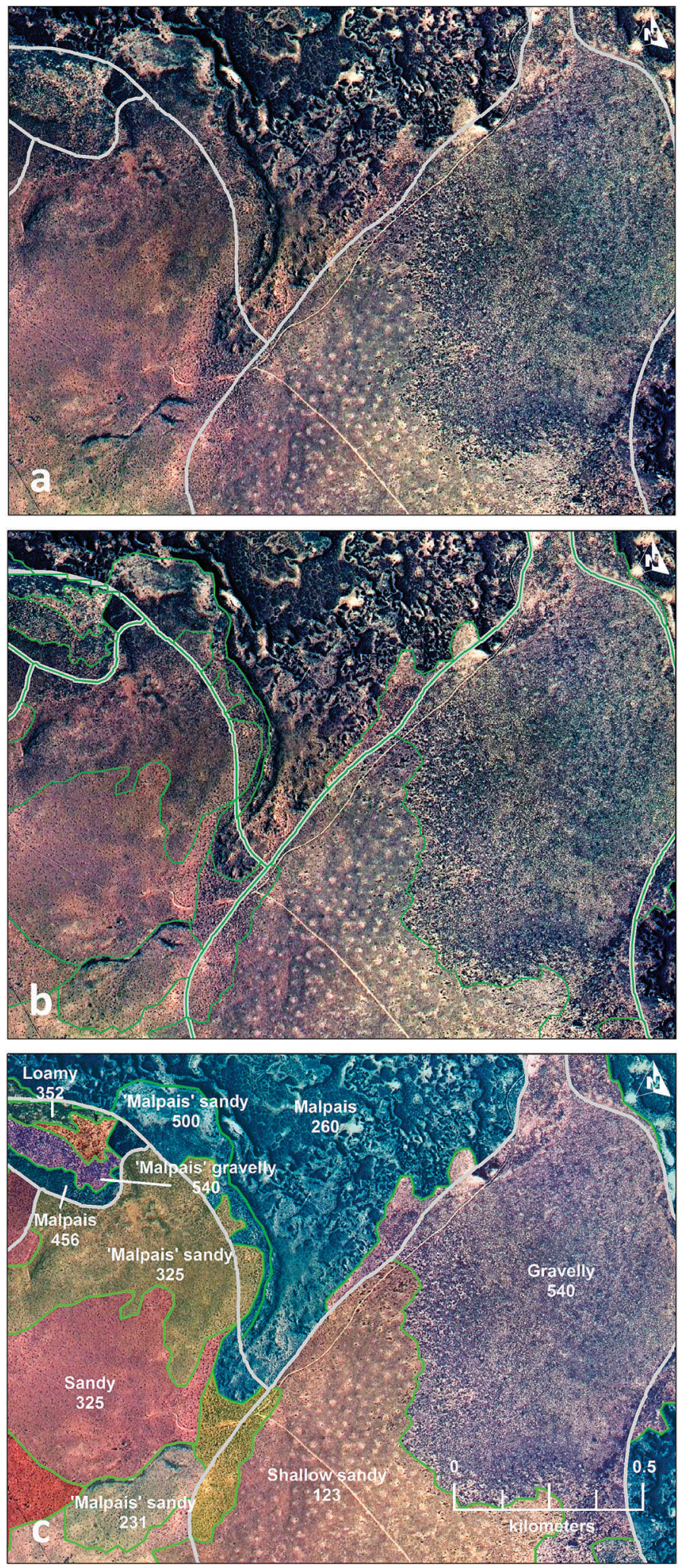

Figure 1. A sequence of steps in state mapping within our study area, including (a) use of soil map unit polygons (white) from the Soil Survey Geographic (SSURG0) Database as a base layer, (b) manual delineation of state map unit polygons (green) residing inside soil map unit polygons, and (c) attribution of ecological site and state codes to each state map unit polygon. A state may cross soil polygon boundaries, but the original soil polygon boundaries remain in the same position and retain their original map unit attributes. We used three state codes (numbers following Table 2) to not alter the shape or attribute data of the original soil map unit polygons. Rather, we created a spatial hierarchy of objects where soil map unit polygons are comprised of "child" constituent polygons. The most important advantage is that nonspatial attributes such as soil map unit code and ecological site are preserved in the new database. In addition to retaining soil map unit ecological site interpretations, we chose to preserve the MLRA classification and the map unit primary key within the SSURGO database. Attribution and interpretation of the state map unit codes (see below) is not possible without ecological site and MLRA classification. Preserving the map unit primary key allows our database to be easily updated if the NRCS makes changes or additions to the SSURGO database.

\section{Applying the State Classification Codes}

Where possible, we used existing field data to apply the state classification to state map unit polygons, but such data were limited. With knowledge of the landscape, geomorphology, land use history, and the appropriate STM, it is possible to identify some states directly from the imagery. For example, there are large expanses of coppice dunes on Sandy ecological sites. At the landscape scale, coppice dunes characterizing an eroded shrubland state form a distinctive polka dot pattern that is easily identifiable on fine resolution imagery. This type of vegetation patterning is associated with an absence of perennial grasses in shrub interspaces (Langford 2000). Other examples of states easily identifiable from imagery are those associated with the coexisting tobosa (Pleuraphis mutica Buckley) and burrograss (Scleropogon brevifolius Phil.) grasslands in Draw and Bottomland ecological sites. Tobosa (Grassland state) and Burrograss (Altered grassland) appear, respectively, as dark and light gray patches in true color photographic imagery. Thus, the two states are visibly distinguishable by color, by their proximity to each other, and by their position in the landscape.

Where a high degree of uncertainty is indicated in state classification, we used rapid field traverses to help classify states. For example, a field traverse is used when there is a disagreement between soil data, ecological site interpretation, and features visible on fine resolution imagery, or if the analyst is unfamiliar with the area. Typically, the analyst identifies key polygons that are representative of problematic areas. Ecological site, state, and vegetation community data are collected within these polygons. A trained expert can determine ecological site and state for 40-100 points, representing 13000 to 25000 ha, in $1 \mathrm{~d}$.

Despite efforts to reduce heterogeneity within map unit polygons, in some areas the patterning of intermingled states occurs at scales finer than those of state mapping. There is a point at which trying to capture each small unit of land in a pure state becomes impractical, both in terms of the time it takes to digitize the polygons and for interpreting the landscape for management activities. To circumvent this problem, we used multiple state codes to indicate the states present in a polygon in decreasing order of estimated areal cover (Fig. 1c).

denote the presence of multiple states in each state map unit, in order of decreasing estimated areal coverage. The state code 0 for the second and/or third digit indicates that no additional states were recorded. 


\section{Managing Error}

The states database and map is under production, so there has not yet been a consistent accuracy assessment of the entire product. Accuracy assessment of these data requires consideration of attribute accuracy (assignation of state classes) as well as the positional and spatial accuracy of the polygons. Attribute errors can arise in two critical and interrelated areas: ecological site type (as discussed earlier) and state code classification. In part, the uncertainty in state classification results from the oneto-many cardinality of the relationship between soil map unit polygons and ecological sites. If a soil map unit polygon translates to two ecological sites of the same type (one to three), this does not affect the state code. However, if the ecological sites are of different types, this introduces error. For example, it is not unusual to find soil map units where different ecological site types are finely intermingled and mapped together as an association. In such cases, the ecological sites can be difficult to distinguish in the imagery resulting in confusion when selecting the appropriate state class.

The simplest method for testing the accuracy of the state attributes is to compare samples of classified data with known classifications from ground samples within an error matrix. The error matrix gives statistical measures of thematic accuracy including the probability that a sample from a particular class has been correctly classified in the map (producer's accuracy) and probability that a point classified in the map has the same class in the ground reference data (user's accuracy). Combined, these two measures give an estimate of overall map accuracy, which if based on point samples, would be the percentage of correctly classified points for all classes combined (Story and Congalton 1986). For the state map, attribute accuracy will initially be assessed with error matrices on an as-needed basis because the collection of ground reference points for the entire study area is very time and labor intensive. Therefore, when public allotments are selected for management intervention (e.g., herbicide treatment), these are assessed for classification accuracy. We anticipate that attribute accuracy assessment will be a valuable exercise, because it will help identify those classes that are more frequently misinterpreted from the imagery.

Error matrices give information on thematic or attribute accuracy, but they do not provide information on the location of map unit polygons and the spatial extent of each class. Spatial errors may arise due to polygon boundary positional errors as well as error introduced by misinterpretation of the imagery. We have observed that our state map unit boundaries may deviate from patches of vegetation in the field by up to $10 \mathrm{~m}$. We consider this deviation to be a composite product of error inherent in the orthorectified imagery, the process of digitizing the polygon, and the accuracy of the global positioning system unit used in the field. We argue that rather than identify all spatial errors, it would be more productive to sample different ecological sites where boundaries between map units can be digitized in the field. The difference in position between field and screen digitized boundaries can be used to estimate of the positional accuracy of polygon boundaries digitized from the aerial photography. Boundary errors of around $10 \mathrm{~m}$ do not have much impact when planning or implementing management protocols. But these errors must be taken into account when establishing monitoring sites, which must be located at sufficient distance from polygon edges to avoid sampling the wrong ecological state and/or edge effects.

Further complexity is introduced into the process with potential updates or changes to the STMs, changes to ecological site descriptions, and the addition of new STMs. As our knowledge grows of vegetation dynamics in different ecological sites, it may become necessary to make changes to the STMs, which may result in alterations to our classification scheme. An example of this is the response of Sandy (Type 1) ecological sites to an unusually wet monsoon season in 2007. Sites previously thought to have lost all perennial grasses to become Expansion Shrubland/Woodland (Mesquite dune state) actually saw abundant production of native perennial bunchgrasses (Peters et al. 2012).

We have designed the ecological states geospatial database so that polygon data reside in a Personal Geodatabase (ArcGIS; Environmental Systems Research Institute 2007). The structure of the ecological states geodatabase and the design of the attribute table associated with the state map unit polygons allow for easy creation of new versions of the state map and database, while archiving older versions. Allowing for database updates makes it possible to manage and correct both spatial and attribute errors. Therefore, when errors are identified through accuracy assessment, these will be corrected in the geodatabase.

\section{APPLICATIONS OF THE ECOLOGICAL STATE MAP}

Federal land managers face the challenge of assessing ecological condition over millions of acres of public land with limited financial and personnel resources (Forbis et al. 2007). Furthermore, land managers are required to design landscape use and restoration protocols that are based on knowledge of the spatial distribution of different ecological conditions. We argue that the creation of a spatial data set that uses a classification system tied directly to STMs will facilitate assessment and decisionmaking for land managers. The collection of states in a landscape determines its cumulative or emergent properties (Bestelmeyer et al. 2011). Thus, using information extracted from STMs, we have been able to create spatially explicit expectations for the behavior of land units and landscapes in response to management decisions.

The ecological state map and database are directly usable by land managers already applying STMs in rangeland health assessment and restoration. The state map has been used to design shrub control treatments intended to promote grassland restoration as part of the BLM's "Restore New Mexico" program (Fig. 2a). Shrub encroachment is not uniform across all public lands, and the application of herbicide for shrub control has had varying results, depending on the shrub species and on the quantity and type of grass species that could repopulate the area after shrub die-back. Spatial data on ecological sites and states have helped to concentrate resources on target shrub species and those areas with sufficient remaining grass cover that are expected to respond well to herbicide application (Bestelmeyer et al. 2009). These spatial data have also informed managers about which areas are currently uneconomical to restore as well as the location of savannas where shrubs are 

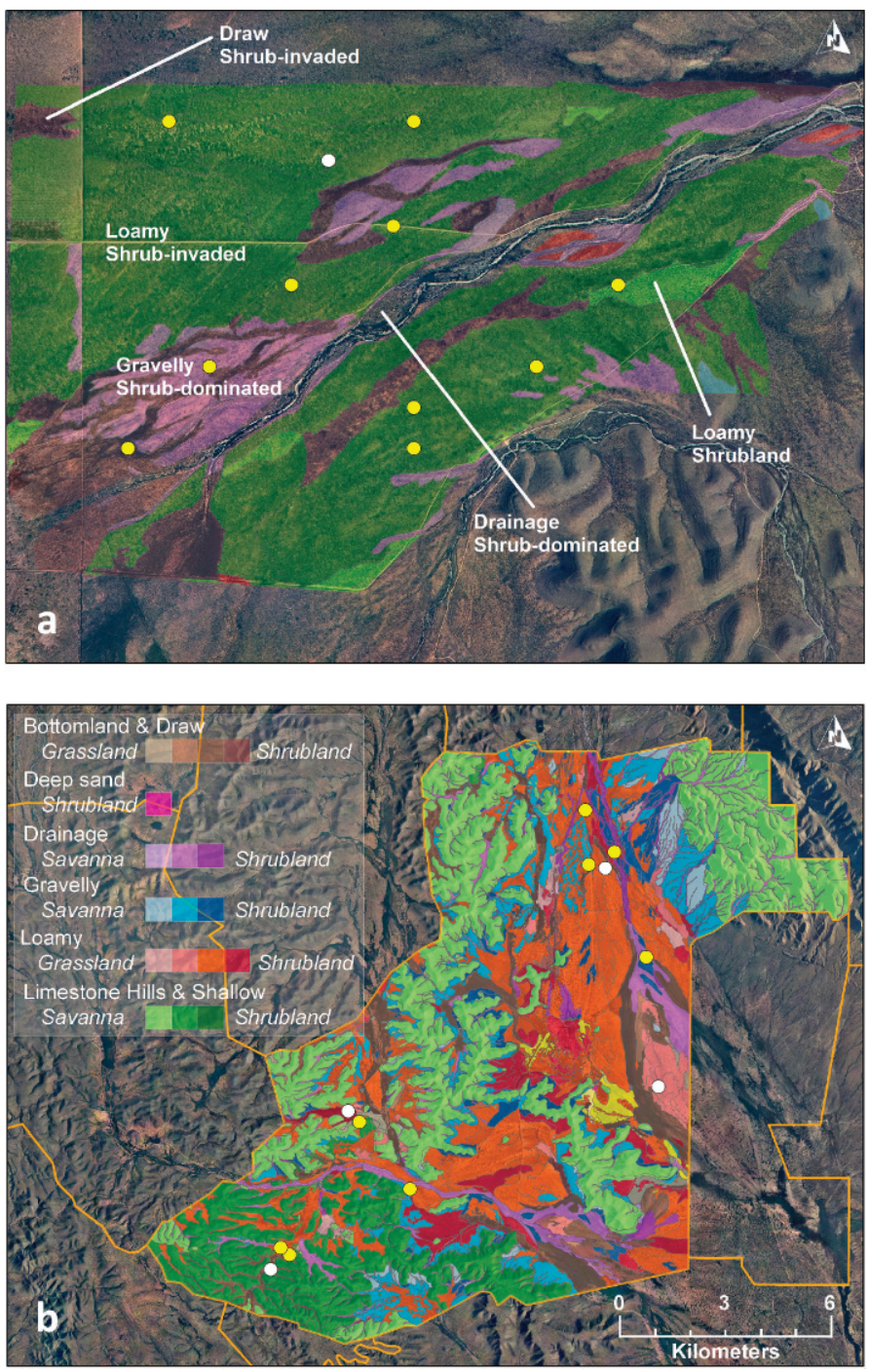

Figure 2. Applications of the ecological state map with the Bureau of Land Management (BLM) Las Cruces District Office. a, A state map used to delineate areas for brush control applications and to stratify monitoring. Drainages and Draw ecological sites were avoided. Monitoring and assessment points (yellow dots) were distributed randomly to distinct states, and the dominant ecological site-state combination was selected for intensive monitoring (white point). b, A state map used to stratify rangeland health assessments, using lowintensity (yellow) and high intensity (white) protocols in different ecological site-state combinations.

regarded as desirable ecosystem components and should be excluded from treatment. Transect-based monitoring data tied to the state mapping database are being collected in these monitoring areas to provide long-term tests of the assumptions represented in STMs. These monitoring data can be used to modify STM structures in the future, as well as the states of map units.

The BLM has also been using the ecological state map to identify suitable areas for solar energy installations. The impact of such installations are extensive (hundreds to thousands of ha) and profound with respect to ecosystem services and land surface albedo. The map and database were used to locate large areas of rangeland that were judged to have crossed irreversible thresholds and as such are unlikely to recover with available restoration technologies (e.g., in some Expansion woodland and Bare states). In this way, the BLM has sought to minimize the detrimental impacts of the development of solar energy installations.

The state map and database are also used as a sampling tool for stratifying point-based assessments of rangeland health indicators. States that exhibit a relatively high risk of difficultto-reverse transitions can be prioritized for assessment (e.g., Shrub-invaded or Shrub-dominated states), whereas highly degraded "irreversible" states (e.g., Expansion Shrubland states) can be made a lower priority because changes to management in these areas are either unnecessary or are likely to be ineffective. Furthermore, when compared to simple random sampling, a priori stratification of the landscape ensures that all potential states are sampled in any given area: uncommon states are not underrepresented and larger, more widespread states are not overrepresented (Fig. 2b).

The state map can also be used as a means to upscale pointbased observations of rangeland attributes (e.g., rangeland health assessment or monitoring data) to larger land areas. Upscaling observations from a point to a land unit requires spatial data that directly correspond with the variables used to characterize states. Ecological sites could be used for upscaling, but this is not an ideal solution because a map unit polygon depicting a single ecological site may contain multiple ecological states. Each land unit recognized for scaling point measurements should depict as homogenous an ecological state as possible. Point-based samples from field visits can then be generalized to the state polygons. This approach also provides a more logical basis than the alternative of simple averaging of rangeland health attributes across a few sample points. Reporting of rangeland health can then be linked to specific land areas, states, and ecological sites, or weighted by area. Moreover, the state map is a visual representation of the location of potential rangeland health problems. For managers, this provides a clear indication of where to focus resources and how to justify their focus to policy-makers and stakeholders.

The fine spatial detail contained within the state map and the information on vegetation dynamics provided by the state classes can also be used to assist interpretation of remote sensing approaches for monitoring and assessments of rangelands. For example, Washington-Allen et al. (2006, 2008) describe procedures for using time-series data from Landsat sensors to assess land degradation and ecological resilience in rangelands. These approaches provide a synoptic view of landscape changes over periods of $15 \mathrm{yr}$ (Washington-Allen et al. 2008) to over three decades (Washington-Allen et al. 2006). Because our classification system is tied to vegetation dynamics captured in the STMs, our state map can be used to assist local interpretation of the landscape scale changes detected by such remotely sensed indicators. In a similar vein, our state map has been used to evaluate long-term, countyscale changes in the cover of ecological states by reclassifying digitized vegetation maps produced in the 1930s (adjudication maps of the BLM) to generalized states and comparing them with our modern state map (Skaggs et al. 2011; Williamson et al. 2011). 


\section{COMPARISON OF THE STATE MAP WITH OTHER CLASSIFICATIONS}

Other types of land classification have been applied in our study area. Two of the most commonly used are the Southwest ReGAP Land Cover Map (Prior-Magee et al. 2007) and the Terrestrial Ecological Unit Inventory (TEUI; Winthers et al. 2005). The ReGAP land cover map is based on the Terrestrial Ecological Systems Classification framework for the conterminous United States (Comer et al. 2003). This approach uses dominant vegetation types as the primary classification factor with regional level physiographic, hydrological, and climatalogical components as secondary factors. In our study area, many of the classes are defined by the indicator shrub species or general functional type and do not consider variations in dominant perennial grass species. For example, large areas are classified as Chihuahuan Mixed Desert and Thorn Scrub or Apacherian-Chihuahuan Mesquite Upland Scrub. This classification obscures areas where perennial grasses may be dominant over or at least codominant with shrubs. The ReGAP land cover map is useful for indicating probable land cover types and vegetation communities at the regional scale, but its applicability for selecting conservation practices in landscapes is limited by its emphasis on existing, dominant vegetation types and coarse scale.

The TEUI system has been developed by the US Forest Service (USFS) and to date has been applied primarily to USFS lands (Winthers et al. 2005). The TEUI system has several parallels with our state classification framework, especially given the focus on including historic and potential states of soils and vegetation for map unit characterization. Both aim to identify, classify, and map ecosystem units according to their potential to support specific types of vegetation, provide ecosystem services, and respond to management actions. Further, the TEUI system also fits into the National Hierarchy of Ecological Units (referred to as the Land Resource Hierarchy by the NRCS). The parallels between the TEUI system and our state classification framework suggest the data are highly complementary. Future linkages of the TEUI system with the ecological site system used in rangelands could facilitate incorporation of TEUI data with state data in a relational database format.

\section{PROSPECTS FOR REMOTE SENSING}

Remote sensing can be useful for monitoring landscapes, but there are situations when remote sensing data alone cannot provide the information required by land managers (Ludwig et al. 2007). We used manual methods to create the state map unit polygons and assign state classes because the interpretation of high resolution imagery needed to classify states in our area did not permit timely production of the state map using automated techniques. There are not always direct relationships between state classes and pixel reflectance, even when using multiple spectral bands. Any relationships that do exist are complicated by within-class variation and between-class similarities. In some cases, there are wide variations in the soil properties, vegetation assemblages, and associated spectral properties (from Terra Advanced Spaceborne Thermal Emission and Reflection Radiometer imagery) within land units assigned to the same state class. We have also observed pixels in different state classes with similar spectral responses in multiple wavebands. Recent approaches using long-term temporal relationships between precipitation and the time-integrated Normalized Difference Vegetation Index modeled on a per-pixel basis have been used to map variations in the cover of certain shrubs, however, and offer a promising approach to state mapping in a variety of contexts (Williamson et al. 2012).

Although pixel-based remote sensing methods for classifying multispectral data are generally not suitable for state classification in our study area, photo interpretation is also not an ideal method. Notably, photo interpretation is time-consuming and susceptible to analyst bias. Object-based image processing methods offer a solution for automation of state classification. Software such as Trimble eCognition (Trimble 2011) or ITT ENVI Fx (ITT 2009) incorporate image segmentation algorithms that can be used to automatically delineate state map unit polygons from remotely sensed imagery. The delineation of image objects by segmentation creates new variables derived from the objects' spatial properties and from contextual relationships with other objects (Blaschke 2010). These variables may be added to the traditional multispectral variables to aid image classification. Object-based image processing also allows for the inclusion of ancillary data in the classification process. Especially important are those variables that the analyst already uses to manually assign land areas to state classes (e.g., digital elevation data, information from existing thematic maps). In our case, soil polygons and data can be incorporated in an object-based approach, meaning that the important attributes such as MLRA, ecological site classification, and soil map unit primary key are preserved.

The choice of classification algorithm to use within the object-based approach for state-mapping will be necessarily one that can handle combinations of categorical and continuous data (e.g., artificial neural networks, support vector machines, decision tree classifiers). Of these, we suggest that the decision tree classifier is the most appropriate because of its computational efficiency and intuitive simplicity (Friedl and Brodley 1997) and because it mimics the decision-making process already being used by the analyst. Several authors have demonstrated how image segmentation can be combined with a decision-tree classifier for classification of natural ecosystems (e.g., Yu et al. 2006; Laliberte et al. 2007). Future work will test this approach and compare it with the photo interpretation method on one or two of the more common ecological sites in our study area.

\section{IMPROVING STMS}

It is important to recognize that, ultimately, the quality of the state map and database for informing management decisions stems from the quality of the STM. Many STMs may include incorrect statements or assumptions about the responses of ecological states to management and natural drivers, or statements may be oversimplified (Boyd and Svejcar 2009; Knapp et al., 2011). Furthermore, the characterization of alternative states and/or ecological sites may be flawed. Nonetheless, assessment and monitoring associated with state mapping provides two means to test and improve the quality of STMs. First, 
the act of state mapping across a landscape necessitates extensive observations. Inconsistencies in how states and ecological sites are defined inevitably appear in these observations, and STMs and ecological site distinctions can be reconsidered as a consequence. Second, monitoring associated with management actions applied to land areas comprising one or more states could be used to test the predictions in STMs and refine them. The cumulative or interactive effects of the coverage and spatial arrangement of states at broad scales might also be examined. These improvements are possible because the state mapping geodatabase format has the capacity to link state polygons to point-based observations. Further, the state polygons can be reclassified or re-delineated, with an ability to track the history of changes that are due to classification errors, changes to STMs, or changes in the actual ecological state on the ground.

\section{MANAGEMENT IMPLICATIONS}

We produced a classification system for and a detailed map of ecological states that supports rangeland management. We feel that this simple idea greatly extends the practical utility of STMs and the science upon which they are based. As we have shown in our study area, maps of states could be used by private and public lands managers to provide science-based, logical, and defensible reasons for applying treatments, assigning monitoring points, and interpreting vegetation trends. State maps connect interpretations from STMs to specific land areas as a basis for these activities. In this paper, we have given examples of how the ecological state map can be used for correctly locating herbicide treatments and for establishing monitoring plots of those treatments. State maps can be applied at broader landscape scales for general monitoring programs of rangeland health, vegetation trends, or other landscape variables providing data that are more suited to broad scales than point or transect-based data. Management personnel can also use the state map to address the multiple-use mandate of public lands (e.g., recreation, grazing, mineral extraction, energy generation), so that potential impacts on sensitive areas are minimized. Related to the applied management of public lands is the ability of the managers to communicate with policymakers and stakeholders. The state maps are a valuable visual representation of our current understanding of the health of public rangelands.

STMs tied to state maps become a link between experimental/observational data gathered at points representing particular ecological sites and states and on-the-ground actions occurring over large landscapes. State maps could be produced in other areas of the United States and the world following the logic and concepts we described. The imagery and classification methods used to map states can vary depending on the attributes defining states, their detectability in remotely sensed and ancillary spatial data, and the spatial scales of homogeneity in ecological sites and states. Applying automated remote sensing techniques to the Chihuahuan Desert landscape is likely to be a greater challenge than to less arid landscapes with more vegetation because of the high degree of within-class variation and between-class similarities discussed earlier. We encourage the exploration of automated remote sensing methods in landscapes that exhibit greater homogeneity of ground cover and where state classes are more closely related to variables derived from remotely sensed data. However, in such efforts, it will be important to recognize that the inherent limitations of STMs (and of the science itself) are reflected in the derivative maps, compounded by classification and spatial errors. For this reason, it is important to view state maps and their databases as dynamic. Point data can be used to correct classifications, polygons can be redrawn, and classification criteria and even systems can change with improved knowledge. A commitment to developing and managing ecological state databases in this way will ensure their long-term utility.

\section{LITERATURE CITED}

Bestelmeyer, B. T., J. E. Herrick, J. R. Brown, D. A. Trujlllo, and K. M. Havstad. 2004. Land management in the American Southwest: a state-and-transition approach to ecosystem complexity. Environmental Management 34:3851.

Bestelmeyer, B. T., A. J. Tugel, G. L. Peacock, Jr., D. G. Robinett, P. L. Shaver, J. R. Brown, J. E. Herrick, H. Sanchez, and K. M. Havstad. 2009. State-andtransition models for heterogeneous landscapes: a strategy for development and application. Rangeland Ecology \& Management 62:1-15.

Bestelmeyer, B. T., X. B. Wu, J. R. Brown, S. D. Fuhlendorf, and G. Fults. 2011. A landscape approach to rangeland conservation practices. In: D. D. Briske [ED.]. Conservation benefits of rangeland practices: assessment, recommendations, and knowledge gaps. Lawrence, KS, USA: Allen Press. p. 337-370.

BLASCHKE, T. 2010. Object based image analysis for remote sensing. ISPRS Journal of Photogrammetry and Remote Sensing 65:2-16.

Boyd, C. S., And T. J. Svejcar. 2009. Managing complex problems in rangeland ecosystems. Rangeland Ecology \& Management 62:491-499.

Briske, D. D., B. T. Bestelmeyer, T. K. Stringham, and P. L. Shaver. 2008. Recommendations for development of resilience-based state-and-transition models. Rangeland Ecology \& Management 61:359-367.

Briske, D. D., S. D. Fuhlendorf, and F. E. Smeins. 2003. Vegetation dynamics on rangelands: a critique of the current paradigms. Journal of Applied Ecology 40:601-614.

Comer, P., D. Faber-Langendoen, R. Evans, S. Gawler, C. Josse, G. Kittel, S. Menard, M. Pyne, M. Reid, K. Schulz, K. Snow, and J. Teague. 2003. Ecological systems of the United States: a working classification of US terrestrial systems. Arlington, Virginia, USA: NatureServe. 75 p.

Di Luzio, M., J. G. Arnold, and R. SRINIvasan. 2004. Integration of SSURGO maps and soil parameters within a geographic information system and nonpoint source pollutions model system. Journal of Soil and Water Conservation 59:123-133.

Environmental Systems Research Institute. 2007. ArcGis for Desktop. Version 9. Redlands, CA, USA: Environmental Systems Research Institute. 8 p.

Forbis, T. A., L. Provencher, L. Turner, G. Medlyn, J. Thompson, and G. Jones. 2007. A method for landscape-scale vegetation assessment: application to Great Basin rangeland ecosystems. Rangeland Ecology \& Management 60:209-217.

Friedl, M. A., and C. E. Brodley. 1997. Decision tree classification of land cover from remotely sensed data. Remote Sensing of Environment 61:399-409.

Fuhlendorf, S. D., W. C. Harrell, D. M. Engle, R. G. Hamilton, C. A. Davis, and D. M. LESLIE, JR. 2006. Should heterogeneity be the basis for conservation? Grassland bird response to fire and grazing. Ecological Applications 16:1706-1716.

ITT. 2009. ENVI feature extraction module. Version 4.6. Boulder, CO, USA: ITT Visual Information Solutions. $6 \mathrm{p}$.

Karl, J. W., and J. E. HerRick. 2010. Monitoring and assessment based on ecological sites. Rangelands 32:60-64.

KarL, M., AND J. SAdowSKI. 2005. Assessing big sagebrush at multiple spatial scales: an example in southeast Oregon. Denver, CO, USA: US Department of the Interior, Bureau of Land Management. Technical note 417. $41 \mathrm{p}$. 
Knapp, C. N., M. E. Fernandez-Gimenez, D. D. Briske, B. T. Bestelmeyer, and X. B. Wu. 2011. An assessment of state-and-transition models: perceptions following two decades of development and implementation. Rangeland Ecology \& Management 64:598-606.

Laliberte, A. S., E. L. Fredrickson, and A. Rango. 2007. Combining decision trees with hierarchical object-oriented image analysis for mapping arid rangelands. Photogrammetric Engineering and Remote Sensing 73:197-207.

Langford, R. 2000. Nabkha (coppice dune) fields of south-central New Mexico, USA. Journal of Arid Environments 46:25-41.

Ludwig, J. A., G. N. Bastin, J. F. Wallace, and T. M. McVicar. 2007. Assessing landscape health by scaling with remote sensing: when is it not enough? Landscape Ecology 22:163-169.

Moseley, K., P. Shaver, H. Sanchez, and B. Bestelmeyer. 2010. Ecological site development: a gentle introduction. Rangelands 32(6):16-22.

Peters, D. P. C., J. Yao, O. E. Sala, and J. Anderson. 2012. Directional climate change and potential reversal of desertification in arid and semiarid ecosystems. Global Change Biology 18:151-163.

Prior-Magee, J. S., K. G. Boykin, D. F. Bradford, W. G. Kepner, J. H. Lowry, D. L. Schrupp, K. A. Thomas, and B. C. Thompson [eds.]. 2007. Southwest regional gap analysis project final report. Moscow, ID, USA: US Geological Survey, Gap Analysis Program. $416 \mathrm{p}$.

RumpfF, L., D. H. Duncan, P. A. Vesk, D. A. Keith, and B. A. Wintle. 2011. State-andtransition modeling for adaptive management of native woodlands. Biological Conservation 144:1224-1236.

Skaggs, R., Z. Edwards, B. T. Bestelmeyer, J. B. Wright, J. Williamson, and P. Smith. 2011. Vegetation maps at the passage of the Taylor Grazing Act (1934): a baseline to evaluate rangeland change after a regime shift. Rangelands 33(1):13-19.

Story, M., and R. G. Congalton. 1986. Accuracy assessment: a user's perspective. Photogrammetric Engineering and Remote Sensing 52:397-399.

Stringham, T. K., W. C. Krueger, and P. L. Shaver. 2003. State and transition modeling: an ecological process approach. Journal of Range Management 56:106-113.

Suding, K. N., AND R. J. HoBbs. 2009. Models of ecosystem dynamics as frameworks for restoration ecology. In: R. J. Hobbs and K. N. Suding [EDS.]. New models for ecosystem dynamics and restoration. Washington, DC, USA: Island Press. p. 3-21.
Trimble. 2011. eCognition. Version 8. Westminster, CO, USA: Trimble Geospatial. $8 \mathrm{p.}$.

USDA-NRCS. 2006. Land resource regions and major land resource areas of the United States, the Caribbean, and the Pacific Basin. USDA Agricultural Handbook 296. Available at: http://soils.usda.gov/survey/geography/mlra. Accessed 1 September 2011.

USDA-NRCS. 2009. National soil survey handbook, title 430-VI. Available at: http://soils.usda.gov/technical/handbook. Accessed 1 September 2011.

Washington-Allen, R. A., R. D. Ramsey, N. E. West, and B. E. Norton. 2008. Quantification of the ecological resilience of drylands using digital remote sensing. Ecology and Society 13:33. Available at: http://www.ecologyandsociety. org/vol13/iss1/art33. Accessed 1 September 2011.

Washington-Allen, R. A., N. E. West, R. D. Ramsey, and R. A. Efroymson. 2006. A protocol for retrospective remote sensing-based ecological monitoring of rangelands. Rangeland Ecology \& Management 59:19-29.

Westoby, M., B. H. Walker, and I. Noy-MelR. 1989. Opportunistic management for rangelands not at equilibrium. Journal of Range Management 42:266274.

Williamson, J. C., B. T. Bestelmeyer, and D. P. Peters. 2012. Spatiotemporal patterns of production can be used to detect state change across an arid landscape. Ecosystems 15:34-47.

Williamson, J. C., L. M. Burkett, B. T. Bestelmeyer, R. Skaggs, and K. M. Havstad. 2011. Reinterpreting historical data for evidence-based shrubland management. Natural Resources and Environmental Issues 17:135-144.

Winthers, E., D. Fallon, J. Haglund, T. Demeo, G. Nowacki, D. Tart, M. Ferwerda, G. Robertson, A. Gallegos, A. Rorick, D. T. Cleland, and W. Robbie. 2005 Terrestrial ecological unit inventory technical guide. Washington, DC, USA: USDA Forest Service, Washington Office, Ecosystem Management Coordination Staff. $245 \mathrm{p}$.

Yu, Q., P. Gong, N. Clinton, G. Biging, M. Kelly, and D. Schirokauer. 2006. Objectbased detailed vegetation classification with airborne high spatial resolution remote sensing imagery. Photogrammetric Engineering and Remote Sensing 72:799-811.

ZonNEVELD, I. S. 1989. The land unit: a fundamental concept in landscape ecology, and its applications. Landscape Ecology 2:67-86. 